\title{
Adoption of Internet Banking Services by Corporate Customers for Forex Transactions Based on the TRA Model
}

\author{
Lufwendo Lishomwa1, Jackson Phiri ${ }^{2}$ \\ ${ }^{1}$ Graduate School of Business, University of Zambia, Lusaka, Zambia \\ ${ }^{2}$ Department of Computer Sciences, School of Natural Sciences, University of Zambia, Lusaka, Zambia \\ Email: L.Lishomwa@gmail.com, Jackson.phiri@cs.unza.zm
}

How to cite this paper: Lishomwa, L. and Phiri, J. (2020) Adoption of Internet Banking Services by Corporate Customers for Forex Transactions Based on the TRA Model. Open Journal of Business and Management, 8, 329-345.

https://doi.org/10.4236/ojbm.2020.81020

Received: December 7, 2019

Accepted: January 6, 2020

Published: January 9, 2020

Copyright $\odot 2020$ by author(s) and Scientific Research Publishing Inc. This work is licensed under the Creative Commons Attribution International License (CC BY 4.0).

http://creativecommons.org/licenses/by/4.0/

\begin{abstract}
The digital banking system provides numerous advantages to customers, however, there is still a lack of trust among some corporate customers. Absence of face-to-face interaction makes it very impersonal. Thus, customers are more comfortable dealing with people in a physical bank setting that provides personalized services as opposed to mechanical interaction. Many customers still do not trust the online mode of service especially for money related transactions. Users who are not familiar with internet banking feel very uncomfortable as they have doubts regarding the accuracy of the transactions done online. The study looked to identify the factors inhibiting the corporate customers of FNB Industrial Branch from adopting internet banking technologies. The data was collected through closed ended questionnaires that were administered face-to-face within FNB Industrial Branch. The study focused on corporate customers and was administered to 132 respondents which represented an $88 \%$ response rate. The data labelling and cleaning were done using SPSS. Cronbach's Alpha was used for measuring the total consistency between all items of the instrument and internal consistency among items for each dimension. After reliability analysis, it was established that the key factors influencing internet banking were: performance expectancy, control factors, social influence and behavioural intention. A simple regression analysis was conducted to test the research hypotheses following the criteria established by considering use of internet for forex transactions as the dependent variable. All of the independent variables were positive but only one was significant at the confidence level of $P \leq 0.05$. Only social influence is said to have an effect on internet use for Forex transactions, therefore, based on the study, social influence would be a stronger factor leading to adoption of internet banking for Forex transactions.
\end{abstract}




\section{Keywords}

Internet Banking Services, Theory of Reasoned Action, Corporate Customers

\section{Introduction}

The digital banking system provides numerous advantages to customers, however, there is still a lack of adoption amongst corporate customers. Despite the young population in Zambia, the adoption of new media technologies seems to be a challenge due to lack of technological know-how as well as educational gaps. Absence of face-to-face interaction makes the banking experience for customers seem impersonal. Thus, for customers who are more comfortable dealing with people in a physical bank setting that provides personalized services rather than mechanical interaction; digital banking is not an ideal alternative. Many customers still do not trust the online mode of service especially for money related transactions. "The role of trust encompasses the exchanges and interactions of a retail bank with its customers on various dimensions of online banking" [1]. Users who are not experienced on the internet banking platform feel uncomfortable as they have doubts regarding the accuracy of the transactions done online.

Internet banking is an innovative platform through which financial organizations and clients are able to access their records, transfer funds and get the most recent data on their monetary items from public or private systems, such as the internet. Internet banking does not only handle the transfer of data between clients living spaces such homes and workplaces and the physical offices of the banks, but additionally manages sales, deals and access to services, all without requiring the client to be on the bank premises. "Among other benefits, e-banking saves time, customers need not visit the bank branch and banks have the opportunity to enhance their customer base thereby experience improved profits" [2].

In the current climate of the information age, First National Bank is looking at decongesting branches by migrating customers from banking within the branch to banking through self-service channels. Many of the corporate customers are making the decision to forego the self-service channels in favour of face to face interaction within the branch.

This points to a knowledge gap between the corporate customers and the bank's effort towards digital migration. The researcher looked to address challenges corporate customers face with regards to the adoption of internet banking services for forex transactions.

Corporate banking is a significant area of a bank's target markets. As a specialty unit, it gives financial administrations to large companies, associations, and organizations. Regularly the services offered bear the sign of world class transactions. Banks send experienced experts to manage their portfolio of cor- 
porate customers. "Not only is corporate banking a coveted banking sector, it is also the hub and centrepiece of relationship management in banking" [3]. "Corporate banking provides tailored systems and products which include foreign exchange, liquidity management, payments, and cash management" [4]. "Professional financial reporting, disciplined management, and management succession plans are some other key features of corporate banking customers and accounts" [3].

Corporate customers are managed by a team of relationship managers and analysts to ensure that they have efficient service. The banks are guaranteed to gain significant revenue from corporate customers. According to [3], banks go the extra mile in order to keep corporate customers satisfied, in return, this keeps them in contention to obtain good corporate clients to improve their lending portfolio.

This study, which investigated the ways that digital banking adoption can be increased was embedded in the Theory of Reasoned Action which helped to identify the areas that the business can focus on. There have been several studies conducted which looked to investigate the lack of adoption of internet banking but few studies used the Theory of Reasoned Action (TRA) as the framework. From the literature that has been reviewed, there have been no research studies in Zambia using the TRA model.

The findings of the study will be of great use to FNB Zambia in order to improve the way digital banking technologies are tailored. The results of this study will further offer service providers a better knowledge and understanding of the typical digital banking user, regarding their information needs and use, thus, adding value to their marketing actions in the field of digital banking. The results of this study will be informative for managers when planning and implementing new digital banking technologies in future FNB projects.

Through the understanding of the clients' perspective of digital banking, the bank will have the capacity to profit on the inborn qualities of new technological innovations and be able to encourage immediate correspondence with clients. Further, this study will be a contribution to empirical research on digital banking information services, specifically to the sub-Saharan Africa experience.

\section{Literature Review}

A case for additive potential for electronic banking exists in Zambia. "This is due to the prevalence of cash-based financial transactions and the high access to, and regular use of, mobile phones among the unbanked" [5]. According to the [6] survey conducted in 2009 only $33.7 \%$ of Zambian adults have access to financial services, leaving $66.3 \%$ financially excluded. This is despite the growth in the number of banks and branches in Zambia. Financial institutions are always on the move to innovate for new e-banking products and some banks are now going into cloud banking to facilitate internet and mobile banking as the next generation of cloud banking [7]. The widespread use of mobile phones has opened the doors to several mobile payment services. Celpay, owned by First Rand Bank 
in South Africa, offers an m-banking solution in Zambia that provides its subscribers with inter-bank transfers, airtime vending via its dealer network, mini automated teller machine (ATM) capabilities and cash on delivery with its built-in mobile ordering application [8].

The National Payment Systems act was enacted in 2007 in order to provide legal backing for the operation of various payment mechanisms in Zambia. The [9] has identified several systems which can be categorized as systematically important payment systems, these payment systems are essential for the flow of finances and their failure could lead to widespread adverse effects for the economy. These systems are;

- Zambian Interbank Payment and Settlement System

- Electronic Funds Transfer System

- Cheque Image Clearing System

[9]

"The Zambian Interbank Payment and Settlement System (ZIPSS) is an electronic payment system in which processing of transactions for settlement takes place continuously on a transaction by transaction basis in real time" [9]. This real time processing allows for more efficient transfer of funds. The new system can help with managing risks associated with high value payments.

The Electronic Funds Transferring System has imposed a new dimension on bank marketing decision makers. [10] noted that electronic banking, also known as electronic fund transfer (EFT), uses computer and electronic technology as a substitute for cheques and other paper transactions. According to [9], it is a simple, safe and speedy way to collect payments since value is given to customers on the same day as it is available with all commercial banks.

The Cheque Image Clearing (CIC) system is a cheque processing and clearing system and allows customers belonging to one bank to write cheques belonging customers of another bank. Similar to Electronic Funds Transfer (EFT) system, the CIC system is operated by the Zambia Electronic Clearing House Ltd (ZECHL) [9].

In a study conducted on the factors affecting customers adoption of internet banking in Egypt, [11] looked at what led customers to use the service with the TAM model as the framework. The study was quantitative and data collection was carried out through distribution of questionnaires in public and private banks. The results of the study pointed to the design of the website, computer literacy and perceived risk as the key factors driving the adoption of the services. The researcher found that ease of use was a major factor for customers as if they perceived the task too complex, they often shied away from attempting to use the service. A limitation that the researcher noted was that the system did not address perceived behavioural control described in the theory of planned behaviour.

The TAM model has also been used in several studies in the Middle East. In a study by [12] the factors that influence the intention of use of Internet banking in Yemen were addressed. Cross-sectional data was collected from 1286 respon- 
dents through a survey. Structural equation modelling was employed to analyse data. The results showed that the determinants of adoption were perceived ease of use, trust of internet banking and also perceived relative advantage. The model confirmed all the hypotheses of the study about the variables playing a significant role in influencing attitudes towards the use of internet banking. The limitations of the study were that the model focused strictly on behavioural intentions and also focused on the environment in Yemen.

There have been some studies which integrated extra elements into the TAM model in order to establish if it played a part. A study done by [13] based on the TAM model added perceived risk, perceived trust and also bank credibility to empirically test the models ability to predict the customers intentions of adopting internet banking based on their perceptions. The study was based in Jordan and used questionnaires which were distributed to 400 graduate students based in four different universities. The researcher used regression analysis to analyse the results and found that the trust element was a significant contributing factor to whether the respondents would proceed to utilize internet banking. The perceived ease of use and perceived usefulness were also key factors leading to adoption in the market. The study was limited because it was distributed in English, assuming that all respondents had a good grasp of the language which would be sufficient enough to ensure the results were reliable. The effects of demographics were also not taken into consideration which may have had a moderating effect on the level of acceptance.

A study conducted in India on the adoption of internet banking looked to expand the TAM to include subjective norm, image, banks initiative and internet banking self-efficacy. These factors identified by [14] were used to examine the internet banking climate in India. A survey questionnaire was administered to 300 respondents. The model that was proposed was analysed using a confirmatory factor analysis approach. The results collected found that the variables in the proposed model had a significant effect on the participants' perception of internet banking. The limitations of the study were that self-reported usage was taken as actual usage and the model created to augment the original TAM had limited explanatory utility.

In the Zambian context, there have been several studies conducted on the factors affecting adoption of mobile banking based on the TAM model. [15] conducted a quantitative study where a total of 384 respondents who held accounts at three different commercial banks were surveyed. The methodology was chosen because the researcher aimed to tailor the research to each of the TAM model constructs. The results analysed using SPSS showed that when the perceived ease of use was high, the user positive attitude towards the system also increases. The relationship between all the constructs of the model yielded positive results, meaning that if all the ratings were high, the respondent would be more likely to use the service. The results of study were that there is a significant positive relationship between perceived ease of use, perceived usefulness, user attitude, external variables, user intention and system use. The re- 
searcher suggested that further research could be conducted in different provinces in order to enhance the knowledge base and also further research using a different model.

A study on the applicability of the TRA model in the context of internet banking intention in Saudi Arabia was conducted in 2013. [16] used structural equation modeling to test whether the theory was applicable in the non-western culture. A survey was administered and a total of 350 respondents properly completed the survey. The researchers looked to create a new model by combining attitude and subjective norms in order to make it more applicable to the Saudi culture. It was discovered that subjective norms play a large part in Saudi internet banking needs as religion and financial transactions are intertwined. The researcher acknowledged that the limitations of the study were that it can only be applied to internet banking customers in Riyadh and there is a possibility of different results if it was conducted in other cities in the kingdom.

The Theory of Reasoned Action was used in a study which sought to understand factors that led to customers adopting internet banking in Jordan. The study which was conducted by [17] in 2011, surveyed 700 public university employees who had already used internet banking services. There was a confirmatory factor analysis performed to determine if the results were reliable and the measurements were valid. The results yielded from the study showed that the respondents had serious intentions to continue using internet banking. The results also showed that both subjective norms and attitude towards the behaviour had a heavy influence on the respondent's behaviour. The major limitation of the study was that it was conducted amongst university employees and as result may not have been a direct representation of the general population.

In a study conducted in Uganda by [18], the researchers looked to determine the behavioural intention to adopt Islamic banking using TRA as the framework. The authors chose to use structural equation modelling to determine the relationship between attitude, subjective norms and public intention to adopt Islamic banking. A questionnaire was administered to collect data from 300 bank customers. The researchers found that subjective norm was influenced positively by attitude. It was determined that attitude also mediates the relationship between subjective norm and intention to use the service.

In a 2016 study on the intention to adopt Islamic banking in Indonesia, [19] adopted the TRA model to determine the effects that the various constructs had on respondents. The data was collected through questionnaires which were distributed to 375 lecturers of 4 different universities. The Cronbach's Alpha score was above 0.7 which showed that the data collected was reliable. The research model was tested using a Partial Least Square Structural Equation Model. The results showed that attitude, subjective norms, religion and pricing had a direct effect on the intention to use the Islamic Banking services. Government support was not statistically significant on the respondents' intention. The researcher concluded that it is necessary for banks to formulate strategies to disseminate 
information on the Islamic Banking services available and also the importance that the religion aspect plays in the services available. However, the study was limited to lecturers which mean that it did not provide a clear picture of society at large.

The review covered studies which had been conducted using different models. Further discussions were conducted on the background of the electronic banking landscape in Zambia. Finally, it was established that the Theory of Reasoned Action had not been used to conduct this type of research in Zambia and the study will help to supplement the current body of literature.

\section{Theoretical Framework}

The theory of reasoned action was invented to address the knowledge gaps in research which resulted from a weak correlation between attitude and voluntary behaviour. The aim of the model was to understand the relationships that drove behaviours. The Theory of Reasoned Action (TRA) suggests that a person's behaviour is determined by their intention to perform the behaviour and that this intention is, in turn, a function of their attitude toward the behaviour and subjective norms [20]. Figure 1 illustrates the steps taken before an individual decides to perform a particular behaviour.

\section{Behavioural Intention}

The theory is based on the assumption that an individual's behavioural intention leads to the actual behaviour. "The best predictor of behaviour is intention or instrumentality (belief that the behaviour will lead to the intended outcome). Instrumentality is determined by three things: their attitude toward the specific behaviour, their subjective norms, and their perceived behavioural control" [21]. "Intention towards a behaviour is shaped by the person's attitudes and subjective

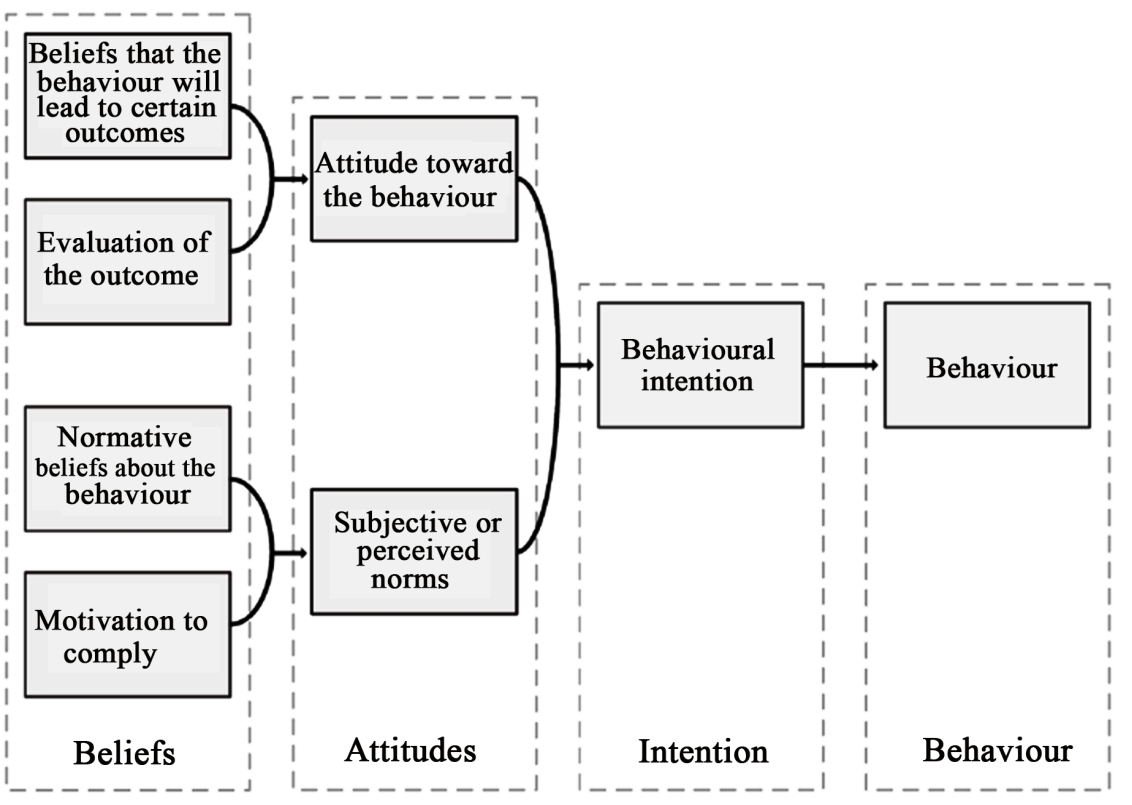

Figure 1. Theory of Reasoned Action (TRA). (Source: Fishbein \& Ajzen, 1975). 
norm (expectancies of social environment) which act as pros and cons towards a behaviour" [22].

This study used Likert scale responses to determine what the exact behavioural intentions of the respondents were. This section of the questionnaire helped identify intended behavioural actions towards internet banking. This was significant because it assisted in establishing whether or not there was a relationship between the behavioural intention of the user and the actual use. According to [23] a behavior is a function of compatible intentions and perceptions of behavioral control in that perceived behavioral control is expected to moderate the effect of intention on behavior, such that a favorable intention produces the behavior only when perceived behavioral control is strong.

\section{Subjective Norms}

The subjective norm is an individuals belief about the desirability of the behaviour. Subjective norms focus on the social desirability of the behaviour. “... subjective norm is a function of the person's beliefs that specific individuals or groups think he or she should, or should not, perform the behaviour. A person who believes that most significant referents think he or she should perform the behaviour will perceive social pressure to do so" [24]. "A high correlation of attitudes and subjective norms to behavioural intention and to behaviour has been confirmed in many studies" [25].

Attitude

Attitude is the degree to which a person perceives the behaviour based on favorable or unfavorable assessment of the behavior ([23] [26]). This entails a consideration of the outcomes of performing the behavior. The attitude of the respondents towards the use of internet banking had a direct effect on whether or not they decided to utilize the service. "Attitude is held to reflect the person's salient behavioural beliefs concerning the possible personal consequences of the action" [24]. Based on the results of the questionnaire, the attitude of respondents also determined whether they were open to learning about how to use the service if they did not know. The belief that using internet banking would be useful to the individual also contributed to the formulation of the attitude.

\section{Methodology}

A research design is defined as the overall technique chosen to incorporate the different components of the study in a logical flow, ensuring that the research problem is effectively addressed [27]. This study utilized descriptive research. The reason for the choice was due to the need to gain an overall view of the research population through the sample; this was achieved through measures of central tendency (mean, median and mode). The additional data obtained through the quantitative study was able to provide an insight into the relationship between the variables.

The research philosophy used for this research was quantitative in nature. This research philosophy was chosen as it excluded or decreased partiality of judgment in results. Furthermore, this research philosophy was best suited as it 
is less time consuming and also provided a snapshot or high-level understanding of the study researched. Lastly, according to [28], this research method aides the researcher to become more objective about the findings of the research as they investigate how independent variables impact on the dependant variables.

The type of sampling that was used for this study was the non-probability sampling method whilst the type of technique that was used was the homogenous purposive sampling technique. With this technique as the framework, corporate customers were administered the questionnaire when they visited the designated corporate banking section at Industrial branch for their particular type of accounts. The reasons that this type of sampling method was chosen was because it focuses on the similarities of individuals who were part of the target population. "This form of sampling ... focuses on candidates who share similar traits or specific characteristic" [29].

For this research, a pilot test was conducted and based on 10 respondents, whose comments served as a basis of amending the final questionnaire. The importance of a pilot study according to [30] is that larger scale studies are typically done so that statistically significant results can be calculated. In such studies, each session needs to be run the same way. As such, a solid script must be created and tested. Reasons for undertaking a pilot study included; developing a research question and research plan, collecting preliminary data, establishing if the sample frame and statistics were effective, refining research questions and assessing the questions validity.

Sample and Data Collection

A questionnaire was the research instrument of choice for this study and is explained to be a list of research questions asked to respondents, such that specific information could be extracted [31]. The main reason why this instrument was chosen over other research instruments is that it ensured suitable information was collected. This allowed for information to be compared and amended to the analysis. Lastly a questionnaire made questions more attractive and diverse. Table 1 shows the sample size and response rate to the questionnaires.

The variables independent variables on the questionnaire were anchored by a 5 -point Likert scale (strongly disagree $=1$, disagree $=2$, neutral $=3$, agree $=4$, strongly agree $=5$ ). The next part of the questionnaire explored behaviour which encompassed use of internet for bank transactions. It measured frequency of use of internet banking and specifically the use of the internet banking services with regards to forex transactions.

Table 1. Sample size and response rates.

\begin{tabular}{cc}
\hline Total population & $\mathrm{N}=1063$ \\
Sample size & $\mathrm{N}=150$ \\
Total responses & 132 \\
Response rate & $88 \%$ \\
\hline
\end{tabular}




\section{Results and Discussion}

\section{Testing Reliability}

Cronbach's Alpha was used for measuring the total consistency between all items of the questionnaire and internal consistency among items for each dimension. Reliability Assessing: internal reliability is important in scales. It raises the question of whether scales are measuring a single idea; hence, whether the items that make up the scale are internally consistent. In this analysis, the Cronbach's alpha was used to calculate reliability. The minimum proposed composite reliability value is 0.70 [32]. Though the Cronbach Alpha of 0.70 is recommended, the minimum alpha of 0.60 sufficed for the early stage of research [33].

Below are the computed Cronbach's Alpha scores for each of the five constructs.

Table 2 showed that the result of the Cronbach's Alpha test was 0.94 for the entire items that greater than 0.70 and each dimension was above 0.60 which is acceptable in social science research.

After reliability analysis, it was observed that Facilitating Conditions yielded a very low Cronbach Alpha score of 0.405 or adjusted score of 0.409 and even when one item was removed in order to raise the internal consistency, the Cronbach's alpha only increased to 0.411 or adjusted score of 0.423 . Therefore, the construct Facilitating Conditions has been completely removed in the analysis. Table 3 shows the adjusted Cronbach's Alpha score for Facilitating Conditions.

Table 2. Cronbach's alpha per construct.

\begin{tabular}{ccccc}
\hline & \multicolumn{5}{c}{ Reliability Statistics } \\
\cline { 2 - 5 } Construct & $\begin{array}{c}\text { Cronbach's } \\
\text { Alpha }\end{array}$ & $\begin{array}{c}\text { Cronbach's Alpha } \\
\text { Based on } \\
\text { Standardized } \\
\text { Items }\end{array}$ & N of Items \\
\hline $\begin{array}{c}\text { Performance } \\
\text { Expectancy } \\
\text { Control } \\
\text { factors }\end{array}$ & 0.793 & 0.794 & 4 & \\
$\begin{array}{c}\text { Social } \\
\text { Influence }\end{array}$ & 0.625 & 0.625 & 4 & \\
$\begin{array}{c}\text { Facilitating } \\
\text { Conditions }\end{array}$ & 0.405 & 0.710 & 5 & 0.758 \\
\hline
\end{tabular}

Table 3. Behavioural Intention after dropping one scale item.

\begin{tabular}{cccc}
\hline & \multicolumn{3}{c}{ Reliability Statistics } \\
\cline { 2 - 4 } Construct & Cronbach's Alpha & $\begin{array}{c}\text { Cronbach's Alpha } \\
\text { Based on } \\
\text { Standardized Items }\end{array}$ & N of Items \\
\hline Facilitating Conditions & 0.411 & 0.424 & 3 \\
\hline
\end{tabular}




\section{Creation of Composite Score}

Having established that only 4 out of the 5 constructs have internal consistency, the composite score for the items has been created using the average score across each construct for each respondent. Table 4 shows the measures of central tendency for the independent variables.

\section{Testing Hypotheses Correlations}

Two correlation analyses were conducted. In the first analysis, the relationship between general use of internet banking and the constructs: performance expectations, control factors, social influence and behavioural intentions as independent variables were explored.

In the second analysis, these independent variables are related to the use of internet for forex transactions.

The results in Table 5 show a very strong relationship between weekly use of internet banking and Performance Expectations, Control Factors and Social Influence. However, there was no relationship between internet use and behavioural intentions.

Table 6 indicates that at a 5\% level of significance, the only variables which have a strong relationship with forex transactions processed using internet banking are social influence and performance expectations.

\section{Regression Analysis}

The simple regression analysis was conducted to test the research hypotheses following the criteria established by [32] considering use of internet for forex transactions as the dependent variable. As discussed under reliability analysis, Facilitating Conditions had a very low Cronbach's Alpha score and is not included in the analysis.

Two regression analyses were conducted. In the first analysis, the relationship between general use of internet banking and the constructs - performance expectations, control factors, social influence and behavioural intentions as independent variables was explored.

Table 7 shows that the standardized coefficient (Beta) values for all independent variables were positive and significant at the confidence level $P \leq 0.05$ except for behavioural intentions. Hence, the decision is to accept the hypothesis

Table 4. Measures of central tendency.

\begin{tabular}{|c|c|c|c|c|c|}
\hline & $\begin{array}{l}\text { Performance } \\
\text { Expectancy }\end{array}$ & $\begin{array}{l}\text { Control } \\
\text { Factors }\end{array}$ & $\begin{array}{c}\text { Social } \\
\text { Influence }\end{array}$ & $\begin{array}{l}\text { Facilitating } \\
\text { Conditions }^{* *}\end{array}$ & $\begin{array}{c}\text { Behavioural } \\
\text { Intention }\end{array}$ \\
\hline Valid & 132 & 132 & 132 & 132 & 132 \\
\hline Missing & 0 & 0 & 0 & 0 & 0 \\
\hline Mean & 3.6667 & 3.2462 & 4.0587 & 3.2008 & 3.0739 \\
\hline Median & 3.6250 & 3.2500 & 4.2500 & 3.2500 & 3.0000 \\
\hline Mode & 4.00 & 3.25 & 4.25 & 3.25 & $2.25 \mathrm{a}$ \\
\hline
\end{tabular}

a. Multiple modes exist. The smallest value is shown. ${ }^{* *}$ Facilitating conditions will not be used in the regression and correlation as it has a very low Cronbach Alpha. 
Table 5. Correlations for weekly use of internet banking.

\begin{tabular}{|c|c|c|c|c|c|c|}
\hline & & $\begin{array}{l}\text { Weekly use of } \\
\text { Internet banking? }\end{array}$ & $\begin{array}{l}\text { Performance } \\
\text { Expectations }\end{array}$ & $\begin{array}{l}\text { Control } \\
\text { Factors }\end{array}$ & $\begin{array}{c}\text { Social } \\
\text { Influence }\end{array}$ & $\begin{array}{l}\text { Behavioural } \\
\text { Intention }\end{array}$ \\
\hline \multirow{3}{*}{$\begin{array}{l}\text { Weekly use of } \\
\text { Internet banking? }\end{array}$} & Pearson Correlation & 1 & $0.469^{* *}$ & $0.364^{* *}$ & $0.393^{* *}$ & 0.156 \\
\hline & Sig. (2-tailed) & & 0.000 & 0.000 & 0.000 & 0.074 \\
\hline & $\mathrm{N}$ & 132 & 132 & 132 & 132 & 132 \\
\hline \multirow{3}{*}{$\begin{array}{l}\text { Performance } \\
\text { Expectations }\end{array}$} & Pearson Correlation & $0.469^{* *}$ & 1 & 0.147 & 0.145 & 0.151 \\
\hline & Sig. (2-tailed) & 0.000 & & 0.093 & 0.096 & 0.083 \\
\hline & $\mathrm{N}$ & 132 & 132 & 132 & 132 & 132 \\
\hline \multirow{3}{*}{ Control Factors } & Pearson Correlation & $0.364^{* *}$ & 0.147 & 1 & $0.306^{* *}$ & 0.117 \\
\hline & Sig. (2-tailed) & 0.000 & 0.093 & & 0.000 & 0.183 \\
\hline & $\mathrm{N}$ & 132 & 132 & 132 & 132 & 132 \\
\hline \multirow{3}{*}{ Social Influence } & Pearson Correlation & $0.393^{* *}$ & 0.145 & $0.306^{* *}$ & 1 & 0.051 \\
\hline & Sig. (2-tailed) & 0.000 & 0.096 & 0.000 & & 0.562 \\
\hline & $\mathrm{N}$ & 132 & 132 & 132 & 132 & 132 \\
\hline \multirow{3}{*}{ Behavioural Intention } & Pearson Correlation & 0.156 & 0.151 & 0.117 & 0.051 & 1 \\
\hline & Sig. (2-tailed) & 0.074 & 0.083 & 0.183 & 0.562 & \\
\hline & $\mathrm{N}$ & 132 & 132 & 132 & 132 & 132 \\
\hline
\end{tabular}

${ }^{*}$ Correlation is significant at the 0.01 level (2-tailed).

Table 6. Correlations for Forex transactions processed using internet banking.

\begin{tabular}{|c|c|c|c|c|c|c|c|}
\hline & & & $\begin{array}{c}\text { forex transactions processed } \\
\text { using internet banking? }\end{array}$ & $\begin{array}{l}\text { Performance } \\
\text { Expectations }\end{array}$ & $\begin{array}{l}\text { Control } \\
\text { Factors }\end{array}$ & $\begin{array}{c}\text { Social } \\
\text { Influence }\end{array}$ & $\begin{array}{l}\text { Behavioural } \\
\text { Intention }\end{array}$ \\
\hline \multirow{15}{*}{$\begin{array}{l}\text { Spearman's } \\
\text { rho }\end{array}$} & \multirow{3}{*}{$\begin{array}{l}\text { forex transactions } \\
\text { processed using } \\
\text { internet banking? }\end{array}$} & Correlation Coefficient & 1.000 & $0.174^{*}$ & 0.142 & $0.176^{*}$ & 0.129 \\
\hline & & Sig. (2-tailed) & & 0.046 & 0.104 & 0.044 & 0.140 \\
\hline & & $\mathrm{N}$ & 132 & 132 & 132 & 132 & 132 \\
\hline & \multirow{3}{*}{$\begin{array}{l}\text { Performance } \\
\text { Expectations }\end{array}$} & Correlation Coefficient & $0.174^{*}$ & 1.000 & $0.187^{*}$ & 0.138 & 0.139 \\
\hline & & Sig. (2-tailed) & 0.046 & & 0.032 & 0.115 & 0.111 \\
\hline & & $\mathrm{N}$ & 132 & 132 & 132 & 132 & 132 \\
\hline & \multirow{3}{*}{ Control Factors } & Correlation Coefficient & 0.142 & $0.187^{*}$ & 1.000 & $0.342^{* *}$ & 0.127 \\
\hline & & Sig. (2-tailed) & 0.104 & 0.032 & & 0.000 & 0.146 \\
\hline & & $\mathrm{N}$ & 132 & 132 & 132 & 132 & 132 \\
\hline & \multirow{3}{*}{ Social Influence } & Correlation Coefficient & $0.176^{*}$ & 0.138 & $0.342^{* *}$ & 1.000 & 0.045 \\
\hline & & Sig. (2-tailed) & 0.044 & 0.115 & 0.000 & & 0.609 \\
\hline & & $\mathrm{N}$ & 132 & 132 & 132 & 132 & 132 \\
\hline & \multirow{3}{*}{$\begin{array}{l}\text { Behavioural } \\
\text { Intention }\end{array}$} & Correlation Coefficient & 0.129 & 0.139 & 0.127 & 0.045 & 1.000 \\
\hline & & Sig. (2-tailed) & 0.140 & 0.111 & 0.146 & 0.609 & \\
\hline & & $\mathrm{N}$ & 132 & 132 & 132 & 132 & 132 \\
\hline
\end{tabular}

${ }^{*}$ Correlation is significant at the 0.05 level (2-tailed). ${ }^{* *}$ Correlation is significant at the 0.01 level (2-tailed). 
Table 7. Standardized coefficient values for independent variables.

\begin{tabular}{|c|c|c|c|c|c|c|c|c|c|}
\hline & \multirow{3}{*}{ Model } & \multirow{2}{*}{\multicolumn{2}{|c|}{$\begin{array}{l}\text { Unstandardized } \\
\text { Coefficients }\end{array}$}} & \multirow{3}{*}{$\begin{array}{c}\text { Standardized } \\
\text { Coefficients } \\
\text { Beta }\end{array}$} & \multirow{3}{*}{$\mathrm{t}$} & \multirow{3}{*}{ Sig. } & \multirow{2}{*}{\multicolumn{2}{|c|}{$\begin{array}{l}\text { 95.0\% Confidence } \\
\text { Interval for B }\end{array}$}} & \multirow{3}{*}{ Hypothesis result } \\
\hline & & & & & & & & & \\
\hline & & B & Std. Error & & & & $\begin{array}{l}\text { Lower } \\
\text { Bound }\end{array}$ & $\begin{array}{l}\text { Upper } \\
\text { Bound }\end{array}$ & \\
\hline \multirow{5}{*}{4} & (Constant) & -0.471 & 0.372 & & -1.267 & 0.208 & -1.206 & 0.265 & Supported \\
\hline & PerfEx & 0.364 & 0.067 & 0.390 & 5.422 & $0.000^{\star * *}$ & 0.231 & 0.496 & Supported \\
\hline & SocialI & 0.202 & 0.056 & 0.266 & 3.593 & $0.000^{\star * *}$ & 0.091 & 0.313 & Supported \\
\hline & ControlF & 0.225 & 0.076 & 0.219 & 2.944 & $0.004^{* *}$ & 0.074 & 0.376 & Not Supported \\
\hline & BehaveI & 0.054 & 0.066 & 0.058 & 0.816 & 0.416 & -0.076 & 0.184 & \\
\hline
\end{tabular}

$\mathrm{R}^{2}=0.613$, Adjusted $\mathrm{R}^{2}=0.357,\left(^{*}\right) p<0.05,\left(^{* *}\right) p<0.01,\left({ }^{* *}\right) p<0.001$.

Table 8. Model summary.

\begin{tabular}{|c|c|c|c|c|c|c|c|c|c|}
\hline \multirow{2}{*}{ Model } & \multirow{2}{*}{$\mathrm{R}$} & \multirow{2}{*}{ R Square } & \multirow{2}{*}{$\begin{array}{l}\text { Adjusted } \\
\text { R Square }\end{array}$} & \multirow{2}{*}{$\begin{array}{l}\text { Std. Error } \\
\text { of the } \\
\text { Estimate }\end{array}$} & \multicolumn{5}{|c|}{ Change Statistics } \\
\hline & & & & & R Square Change & F Change & df1 & df2 & Sig. F Change \\
\hline 1 & $0.469^{\mathrm{a}}$ & 0.220 & 0.214 & 0.621 & 0.220 & 36.754 & 1 & 130 & 0.000 \\
\hline 2 & $0.573^{\mathrm{b}}$ & 0.328 & 0.318 & 0.579 & 0.108 & 20.642 & 1 & 129 & 0.000 \\
\hline 3 & $0.611^{c}$ & 0.373 & 0.358 & 0.561 & 0.045 & 9.218 & 1 & 128 & 0.003 \\
\hline 4 & $0.613 d$ & 0.376 & 0.357 & 0.562 & 0.003 & 0.666 & 1 & 127 & 0.416 \\
\hline
\end{tabular}

a. Predictors: (Constant), PerfEx; b. Predictors: (Constant), PerfEx, SocialI; c. Predictors: (Constant), PerfEx, SocialI, ControlF; d. Predictors: (Constant), PerfEx, SocialI, ControlF, BehaveI

Table 9. Coefficient values after model summary.

\begin{tabular}{|c|c|c|c|c|c|c|c|c|c|}
\hline & \multirow{2}{*}{ Model } & \multicolumn{2}{|c|}{ Unstandardized Coefficients } & \multirow{2}{*}{$\begin{array}{c}\text { Standardized } \\
\text { Coefficients }\end{array}$} & \multirow{2}{*}{$\mathrm{t}$} & \multirow{2}{*}{ Sig. } & \multicolumn{2}{|c|}{$95.0 \%$ Confidence Interval for B } & \multirow{2}{*}{ Hypothesis result } \\
\hline & & B & Std. Error & & & & Lower Bound & Upper Bound & \\
\hline \multirow{2}{*}{1} & (Constant) & 0.791 & 0.179 & & 4.423 & 0.000 & 0.437 & 1.145 & \multirow{3}{*}{ Supported } \\
\hline & SocialI & 0.104 & 0.043 & 0.207 & 2.414 & 0.017 & 0.019 & 0.189 & \\
\hline \multirow{5}{*}{2} & (Constant) & 0.282 & 0.299 & & 0.943 & 0.347 & -0.309 & 0.873 & \\
\hline & SocialI & 0.084 & 0.045 & 0.169 & 1.873 & 0.063 & -0.005 & 0.174 & Supported \\
\hline & PerfEx & 0.081 & 0.054 & 0.131 & 1.498 & 0.137 & -0.026 & 0.187 & Not Supported \\
\hline & ControlF & 0.032 & 0.061 & 0.047 & 0.520 & 0.604 & -0.090 & 0.153 & Not Supported \\
\hline & BehaveI & 0.061 & 0.053 & 0.100 & 1.158 & 0.249 & -0.043 & 0.166 & Not Supported \\
\hline
\end{tabular}

a. Dependent Variable: How many forex transactions have you processed using internet banking?

Table 10. Model comparison of independent variables.

\begin{tabular}{|c|c|c|c|c|c|c|c|c|c|}
\hline \multirow{2}{*}{ Model } & \multirow{2}{*}{$\mathrm{R}$} & \multirow{2}{*}{ R Square } & \multirow{2}{*}{ Adjusted R Square } & \multirow{2}{*}{$\begin{array}{l}\text { Std. Error of } \\
\text { the Estimate }\end{array}$} & \multicolumn{5}{|c|}{ Change Statistics } \\
\hline & & & & & R Square Change & F Change & df1 & df2 & Sig. F Change \\
\hline 1 & $0.207^{\mathrm{a}}$ & 0.043 & 0.036 & 0.455 & 0.043 & 5.829 & 1 & 130 & 0.017 \\
\hline 2 & $0.279^{\mathrm{b}}$ & 0.078 & 0.049 & 0.451 & 0.035 & 1.599 & 3 & 127 & 0.193 \\
\hline
\end{tabular}

a. Predictors: (Constant), SocialI; b. Predictors: (Constant), SocialI, BehaveI, PerfEx, ControlF. 
for all independent variables excluding behavioural intentions. Clearly, there is a significant positive relationship between the independent variables of PerfEx, Sociall, and ControlF.

Table 8, the model below gives a summary of the 4 models for predicting the influence of the 4 independent variables on use of internet banking. The conclusions are based on model 4 as highlighted above and in the table below.

In the second analysis, these independent variables (IV) are related to the use of internet for forex transactions (DV). Table 9 shows that the standardized coefficient (Beta) values for all independent variables were positive and but only one was significant at the confidence level $\mathrm{P} \leq 0.05$. Only social influence is said to have an effect on internet use for forex transactions. As observed in model 1 in Table 10, $P$ value $=0.017$. Therefore, the decision is to accept the hypothesis for social influence and reject for all independent variables. There is no significant positive relationship between the independent variables of PerfEx, BehaveI and ControlF with use of internet banking for forex transactions.

In summary, the findings of this research indicate that from a sample size of 150 FNB Industrial branch corporate customers, 132 fully completed the questionnaire which resulted in an $88 \%$ response rate. Cronbach's Alpha was used to measure the internal consistency of the independent variables. It was discovered that facilitating conditions yielded a score which was below the acceptable range and as a result was not considered in the final analysis. A correlation analysis was used to measure the independent variables against the dependent variable of weekly use of internet banking. All the independent variables apart from behavioural intention showed that there was a relationship between the factors at a $5 \%$ level of significance. When the independent variables were measured against the dependent variable of internet use for forex transactions, only performance expectancy and social influence showed a relationship at 5\% level of significance.

Lastly, two regression analyses were conducted to measure the relationship between the independent variables and the use of the internet banking in general, as well as, the independent variables and use the use of internet banking for forex transactions. The results for the first regression analysis showed that there was a relationship between the dependent variable and all the independent variables except for behavioural intentions. The second, regression analysis showed that the only independent variable which had a relationship with the use of internet banking for forex transactions was social influence. Thus, it can be deduced that social influence is the major determining factor behind the intention of the respondents to use internet banking for forex transactions.

\section{Conclusions}

The research study sought to identify the factors that were inhibiting customers from performing online payments for forex transactions. The findings of this study show that the primary data answered the research question. This is be- 
cause data on the above-mentioned objective was retrieved and showed that social influence is the major driving force behind the intention of corporate customers to use internet for forex transactions. There were two hypothesis tests conducted, a correlation and regression analysis.

The correlation results found that there was a relationship between the performance expectation, control factors and social influence when it came to the weekly use of internet banking. However, there was no relationship with behavioural intention and use of internet banking. When the independent variables were measured against the dependent variable of the use of internet banking for forex transactions, only social influence and performance expectancy had a relationship on the respondents' intention to utilize the service.

The regression test conducted highlighted that social influence, with a significance level of 0.017 , was the only independent variable which was supported at $0.05 \%$ level of significance. This showed that the respondents were influenced by social pressure which ultimately led to the decision of whether or not they intended to use the internet banking service for their forex transactions.

\section{Recommendations}

In the ever-changing banking industry, the only leverage that banks possess is the ability to adapt to the demands of their customers. This ability to adapt will help to differentiate banks from the competition.

The study found that the social influence had the largest impact on the decision to use internet banking. Lack of awareness is the most important factor that negatively affects internet banking adoption [34]. The increased online presence will open up a new avenue to reach customers who would not normally pay attention to traditional advertising campaign. Due to the larger reach and ability for customers to share the advertisement by choice in the case of Facebook, it will allow the knowledge of the product to organically grow.

The customers may be more encouraged to use the internet banking platform for forex transactions if the functionality was included on the banking application for smartphones. The study showed that $84.1 \%$ of respondents believed that internet banking would be useful in carrying out their tasks which means that the respondents see the value in the service. The results also indicated that $98 \%$ of respondents use the internet at least for 1 hour per day, which means that the target market is already active and with easier accessibility it would be possible to encourage users to take advantage of the bank products.

The study was one of the few to focus on the topic using the theory of reasoned action. Further research can be done at other branches using the same theory in order to expand the literature and gain a more holistic picture of the market. Further studies would be able to supplement the findings of this study and help FNB and other organizations streamline future marketing strategies. 


\section{Conflicts of Interest}

The authors declare no conflicts of interest regarding the publication of this paper.

\section{References}

[1] Mukherjee, A. and Nath, P. (2003) A Model of Trust in Online Relationship Banking. International Journal of Bank Marketing, 21, 5-15. https://doi.org/10.1108/02652320310457767

[2] Okibo, B.W. and Wario, A.Y. (2014) Effects of e-Banking on Growth of Customer Base in Kenyan Banks. International Journal of Research in Management \& Business Studies, 1, 78-84.

[3] Onyiriuba, L. (2016) Emerging Market Bank and Credit Risk Control. Elsevier, London.

[4] Kumar, R. (2014) Strategies of Banks and Other Financial Institutions. Elsevier, London.

[5] Adongo, J. (2007) The Potential for Mobile Banking in Zambia. http://www.finmark.org.za/wp-content/uploads/2016/02/Rep potentialforMobileBa nking Zambia 2007.pdf

[6] Finscope (2009). https://www.boz.zm/FinScope-Zambia-2009-Top-Line-Findings.pdf

[7] Nuwagaba, A. and Brighton, M. (2014) Analysis of E-Banking as a Tool to Improve Banking Services in Zambia. International Journal of Business and Management Invention, 3, 62-67.

[8] Mulambo, M. (2007) Celpay. Presentation on Making Finance Work for Africa Conference at the World Bank, Washington DC.

[9] Bank of Zambia (2019) Financial and Other Statistics. Bank of Zambia, Lusaka.

[10] Andam, Z.R.B. (2003) E-Commerce and e-Business. http://www.apdip.net/publications/iespprimers/eprimer eCom.pdf

[11] Fawsy, S.F. (2017) Internet Banking Adoption in Egypt. Journal of Business and Retail Management Research, 12, 49-57.

[12] Al-Ajam, A.S. and Nor, M.K. (2013) Internet Banking Adoption: Integrating Technology Acceptance Model and Trust. European Journal of Business Management, 5 , 17-20.

[13] Alkailani, M. (2016) Factors Affecting the Adoption of Internet Banking in Jordan: An Extended TAM Model. Journal of Marketing Development and Competitiveness, 10, 15-22.

[14] Marakarkandy, B., Yajnik, N. and Dasgupta, C. (2017) Enabling Internet Banking Adoption. Journal of Enterprise Information Management, 30, 263-294. https://doi.org/10.1108/JEIM-10-2015-0094

[15] Sakala, L. and Phiri, J. (2019) Factors Affecting Adoption and Use of Mobile Banking Services in Zambia Based on TAM Model. Open Journal of Business and Management, 7, 1380-1394. https://doi.org/10.4236/ojbm.2019.73095

[16] Albarq, A. and Alsughayir, A. (2013) Examining Theory of Reasoned Action in Internet Banking Using SEM Among Saudi Consumers. International Journal of Marketing Practices, 1, 16-30.

[17] Al-Majali, M. (2011) The Use of the Theory of Reasoned Action to Study Information Technology in Jordan. Journal of Internet Banking and Commerce, 16, 
197-228.

[18] Lujja, S., Mohammad, M.O. and Hassan, R. (2016) Modeling Public Behavioural Intention to Adopt Islamic Banking in Uganda. International Journal of Islamic and Middle Eastern Finance and Management, 9, 233-240. https://doi.org/10.1108/IMEFM-08-2015-0092

[19] Reni, A. and Ahmad, N. (2016) Application of Theory of Reasoned Action in Intention to Use Islamic Banking in Indonesia. Journal of Islamic Economics, 8, 49-57.

[20] Fishbein, M. and Ajzen, I. (1975) Belief, Attitude, Intention, and Behavior: An Introduction to Theory and Research. Addison-Wesley, Reading.

[21] Luxton, D.D. (2016) Artificial Intelligence in Mental Healthcare. Elsevier, New York.

[22] Hammond, A. and Niedermann, K. (2010) Rheumatology. Churchill Livingstone, Edinburgh.

[23] Ajzen, I. (1991) The Theory of Planned Behaviour. Organizational Behaviour and Human Decision Processes, 50, 179-211. https://doi.org/10.1016/0749-5978(91)90020-T

[24] Sutton, S. (2001) Health Behaviour: Psychosocial Theories. In: Smelser, N.J. and Baltes, B., Eds., International Encyclopedia of Social and Behavioural Sciences, Elsevier, Oxford, 6499-6506. https://doi.org/10.1016/B0-08-043076-7/03872-9

[25] Sheppard, B.H., Hartwick, J. and Warshaw, P. (1998) The Theory of Reasoned Action: A Meta-Analysis of Past Research with Recommendations for Modifications and Future Research. Journal of Consumer Research, 15, 325-343. https://doi.org/10.1086/209170

[26] Ajzen, I. and Fishbein, M. (2004) Questions Raised by a Reasoned Action Approach: Comment on Ogden. Health Psychology, 23, 431-434. https://doi.org/10.1037/0278-6133.23.4.431

[27] Creswell, J.W. (2013) Research Design: Qualitative, Quantitative, and Mixed Methods Approaches. Sage Publications, Thousand Oaks.

[28] Mertens, D.M. (2014) Research and Evaluation in Education and Psychology: Integrating Diversity with Quantitative, Qualitative, and Mixed Methods. Sage Publications, New York.

[29] Etikan, I., Musa, S.A. and Alkassim, R.A. (2016) Comparison of Convenience Sampling and Purposive Sampling. American Journal of Theoretical and Applied Statistics, 5, 1-4.

[30] Saunders, M.N.K., Lewis, P. and Thornhill, A. (2012) Research Methods for Business Students. Pearson, Harlow.

[31] Bernard, H.R. and Gravlee, C.C. (2014) Handbook of Methods in Cultural Anthropology. Rowman \& Littlefield, Lanham.

[32] Hair, J.F., Black, W.C., Babin, B.J. and Anderson, R.E. (2010) Multivariate Data Analysis. 7th Edition, Pearson, New York.

[33] Nunnally, J.C. (1978) Psychometric theory. 2nd Edition, McGraw-Hill, New York.

[34] Sathye, M. (1999) Adoption of Internet Banking by Australian Consumers: An Empirical Investigation. The International Journal of Bank Marketing, 17, 324-334. https://doi.org/10.1108/02652329910305689 